\title{
Rheumatoid Factor Antibody IgA Measurement
}

National Cancer Institute

\section{Source}

National Cancer Institute. Rheumatoid Factor Antibody IgA Measurement. NCI

Thesaurus. Code C120652.

The determination of the rheumatoid factor antibody IgA present in a sample. 